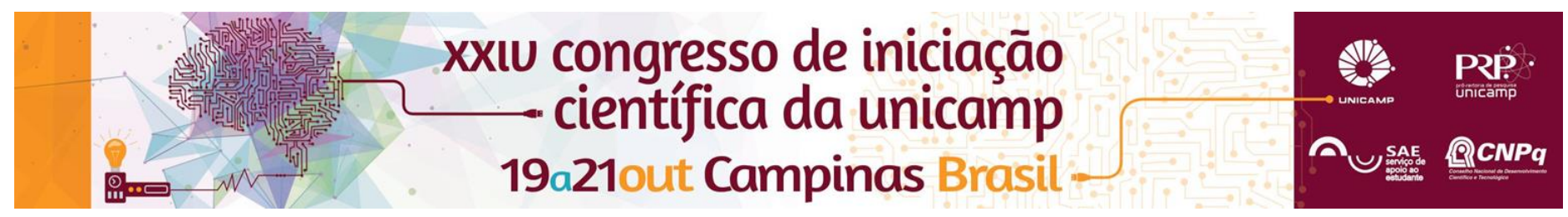

\title{
MARACATÚ NAÇÃO PORTO RICO: DAS LOAS À LOUVAÇÃO, DO BAQUE AO TOQUE
}

\section{Suelen Turibio Lopes}

\section{Resumo}

Este trabalho irá discorrer sobre a musicalidade da nação de maracatú Porto Rico, de Recife-PE e a relação direta dela com a religião do candomblé demonstrada através de vários elementos que compõe esse maracatú: desde as loas (canções), o baque (toque), a indumentária dos músicos, os instrumentos. Tudo que compõe essa manifestação, para a nação Porto Rico, tem um significado religioso, um fundamento, que é difundido nas apresentações feitas pelo maracatú.

Palavras-chave:

Maracatú, Baque virado, Loas

\section{Introdução}

Esse trabalho sintetiza alguns aspectos que mostram a importância que a religiosidade do candomblé tem dentro do maracatú Porto Rico e como esse conhecimento ajuda na interpretação do percussionista ao executar as loas, o que pude comprovar também através das mudanças que se realizaram na maneira como eu toco e ensino maracatú de baque virado.

\section{Resultados e Discussão}

A riqueza de detalhes presentes na execução desse gênero faz com que o som se transforme nas mãos de um batuqueiro que conhece a história da nação, a simbologia dos orixás, como são as danças deles nos rituais religiosos do candomblé, quais as particularidades dos toques para saudar cada um e como representar isso com o instrumental percussivo que compõe a bateria do maracatú.

Na Nação Porto Rico, o mestre Chacon no ano 2000, introduziu no corpo de percussão instrumentos que provavelmente faziam parte do baque, mas que por alguma razão foram banidos e esquecidos pelas nações de maracatu de baque virado. Chacon afirma ter feito "resgate do que os maracatús tinham de mais sagrado, trazendo novamente os agbês e os atabaques ao baque que tradicionalmente fazia parte do maracatú e estava sendo negligenciado, esquecido." (palestra concedida em 23 de novembro de 2013 - Ribeirão Preto - SP).

No caso, o Ylé Axé Oxóssi Guangobira, onde está o Ponto de Cultura da Nação Porto Rico, que é um terreiro de candomblé de tradições Jeje e Nagô, as cores verde e vermelho são símbolos importantes por corresponderem ao orixá Ogún, patrono da Nação. Assim como as cores, temos a caravela que se chama Santa Maria, o mar representado no "baque das ondas", efeito característico ao sotaque do Porto Rico, identificado na forma de tocar os instrumentos e na movimentação do corpo dos percussionistas.

\section{Conclusão}

Acredito ter alcançado as metas propostas no início do projeto, embora com muitas dificuldades quanto à organização e distribuição do tempo entre as pesquisas práticas e teóricas, que somente foram superadas no segundo semestre de trabalho. Após certas reuniões com o orientador, foi possível trabalhar de forma mais equilibrada e produtiva na parte teórica.

Em se tratando dos objetivos, creio ter logrado principalmente demonstrar a relação entre o candomblé e o maracatú da nação Porto Rico, com exemplos que podem auxiliar a quem quiser conhecer um pouco mais sobre a musicalidade dessa manifestação cultural, e contribuindo para agregar significados ás interpretações percussivas do maracatu com esse sotaque.

\section{Agradecimentos}

Só tenho a agradecer ao SAE, ao meu orientador prof. Dr. Leandro Barsalini, ao mestre Chacon Viana e todos componentes do Porto Rico pela oportunidade de vivenciar essa experiência mais que musical e que contribui para minha formação acadêmica além de aprofundar o significado e a importância da pesquisa dentro e fora da universidade.

\footnotetext{
CUNHA, Gloria Pereira. Depoimento registrado dia 27/08/2015 cedido à autora. https://www.youtube.com/watch?v=gDi2PIoZJyA

- FREITAS, Emília Maria Chamone de. O Gesto musical nos métodos de percussão afro-brasileira. 80p. 2008. Dissertação do mestrado em Música UFMG. Belo Horizonte.

MAAKAROUN, Eugênia de Freitas. Maracatu: Ritmos Sagrados Belo Horizonte, 2005. Dissertação do mestrado em Artes Visuais da Escola de Belas Artes da UFMG. Disponível em https://www.youtube.com/watch?v=3bT5vVWvgYo

- PINTO, Tiago de Oliveira. As cores do som: estruturas sonoras e concepção estética na música afro-brasileira. África: Revista do Centro de Estudos Africanos. USP, São Paulo, 22-23; 87-109, 1999/2000.

- PORTO RICO, Maracatú. Nação de Maracatu Porto Rico, disponível em http://nacaoportorico.maracatu.org.br/ . Acesso em 04/04/2014.

- VIANA, Jailton Shacon. Oficina de toques de atabaque no Maracatú ofertada em Campinas na Casa de Cultura Tainã. Áudio - 44:02min.

- VIANA, Jailton Shacon. Palestra ministrada em 29/11/2013 em Campinas na Casa de Cultura Tainã. Áudio - 46:17min. Bibliografia

-REAL, Katarina. Eudes: o rei do maracatu. 148p. Recife. Fundaj, Massangana, 2001

-SANTOS, Climério de Oliveira e RESENDE, Tarcísio Soares. Maracatu: Baque Virado e Baque Solto. V.1. 154p. Pernambuco. Recife. 2005

-VIANA, Jailton Shacon. Entrevista concedida à autora do projeto em 23/11/2013 em Ribeirão Preto. Áudio - 12:21min.
} 